\title{
STUMP SPROUTING OF FELLED TREES OF 33 SPEGIES IN A SELEGTIVELY LOGGED AND SILVICULTURALLY TREATED FOREST IN SURINAME
}

\author{
Jagernath $\mathrm{R}^{1}$, Landburg JS ${ }^{1}$, Paal $\mathrm{AP}^{2}$, Sewdien $\mathrm{AV}^{3}$, Ospina $\mathrm{A}^{4}$, Wortel $\mathrm{V}^{5} \& \mathrm{Putz}^{\mathrm{F}} \mathrm{F}^{6}$ * \\ ${ }^{1}$ Foundation for Forest Management and Production Control (SBB), Ds. M.L. Kingweg perc. 283, Paramaribo, Suriname \\ ${ }^{2}$ Caribbean Regional Organization for Forestry and Timber (CROFT), - Nature Eं Environment Unit at the Chamber of \\ Commerce and Industry Prof. W.J.A. Kernkampweg \#37, Paramaribo, Suriname \\ ${ }^{3}$ Anton de Kom University of Suriname (AdeKUS), Sustainable Management of Natural Resources, Leysweg 86, Paramaribo, \\ Suriname \\ ${ }^{4}$ Tropical Agricultural Research and Higher Education Center (CATIE), Cartago Province, Turrialba, Costa Rica \\ ${ }^{5}$ Department of Forest Management, Centre for Agricultural Research in Suriname (CELOS), Prof. Dr. Ir. J. Ruinardlaan, \\ Paramaribo, Suriname \\ ${ }^{6}$ Department of Biology, University of Florida, Gainesville, FL 32611-8526, USA
}

*fep@ufl.edu

Submitted March 2021; accepted June 2021

\begin{abstract}
To evaluate the contributions of sprouted stumps to stand conditions after selective logging and liberation thinning around future crop trees, we censused the stumps of 120 trees belonging to 33 species in a lowland forest in Suriname. Nearly half of the stumps supported live sprouts 13-18 months after felling. The likelihood of sprouting varied among the 33 species sampled and was lower among stumps of large diameter and thick bark. Sprouting was not related to stump height, topographic location, or canopy cover. To avoid competition from stump sprouts, we recommend that poison girdle be used for liberation treatments.
\end{abstract}

Keywords: Stump sprouts, liberation thinning, coppicing

\section{INTRODUCTION}

Sprouting from cut, burned and broken stems is a form of vegetative recovery of aboveground tissues of which many tree species are capable. The capacity to sprout is of particular importance in ecosystems subjected to frequent large-scale natural disturbances such as hurricanes and fire (Byer \& Weaver 1977, Ewel 1977, Stocker 1981, Uhl et al. 1981). Stump sprouting also occurs after logging (Bellingham \& Sparrow 2000, Del Tredici 2001, Fuashi et al. 2020, Ramdial et al. 2020) and slash-and-burn agriculture (De Rouw 1993, Peltier et al. 2014) even in ecosystems where top-killing disturbances are uncommon and not considered important in the evolutionary history of the species. One explanation for the retention of the capacity to sprout is that, even in forests where cataclysmic events are infrequent, many woody plants suffer stem damage from smaller-scale disturbances such as branch and tree fall (e.g. Clark \& Clark 1991, Paciorek et al. 2000) as well as breakage by large animals (Ickes et al. 2003). Everham and Brokaw (1996) suggested that sprouting is more common among tropical than temperate tree species, but the latter are much better studied. This argument is supported by a study of sprouting post-logging in a semi-deciduous forest in Uganda by Mwavu and Witkowski (2008) who reported that 814 of 835 stumps sprouted, which comprised 119 species of 31 families.

Despite the prevalence of stump sprouting, some species and phylogenetic lineages of trees lack this capacity or lose it when they become large. Examples of the phylogenetic effect are that few pines (Pinus spp.) or dipterocarps (Dipterocarpaceae spp.) sprout whereas sprouting is common among oaks (Quercus spp.) and eucalypts (Eucalyptus spp.). Within plant communities, whether or not a stump sprouts is likely determined by its characteristics as well as by environmental conditions (Clarke et al. 2013). Many studies reported that the sprouting ability of trees typically decreases as they become older and larger (Lust \& Mohammady 1973). 
In contrast, coppiced stumps of several metres diameter have been in production for centuries in Europe (Rackham 1980). The number of sprouts per stump often increases with stump diameter until bark thickness, which increases with tree diameter, hinders bud emergence. Several authors reported that sprout survival decreases with stump height (Lust \& Mohammady 1973, Keim et al. 2006). How height affects sprouting is not clear but stumps (i.e. stools) managed for coppice are typically cut low to the ground (Evans 1992). A large number of tree stems were snapped after a windstorm in Panama and Putz and Brokaw (1989) observed a high initial proportion of sprouted stems but then diminishing numbers of live sprouts over the first year. Several authors suggested that exposure to light promotes stump sprouting (e.g. Lust \& Mohammady 1973), but the mechanism for this purported phenomenon is not clear.

Stump sprouting is the basis for coppice management, a forestry technique employed at least since the Bronze Age (Rackham 1980) and still employed for commercial production of wood fibre, fuel, and small dimension building materials (e.g. Evans 1992). In contrast, stump sprouting is undesirable in stands managed for trees grown directly from seeds that suffer from competition from stump sprouts. Shade cast by stump sprouts might be important, but belowground competition may be of particular importance where soils are nutrient-poor and water availability is at least seasonally limited (Putz \& Canham 1992, Coomes \& Grubb 2000). Furthermore, long-term retention of live stumps may increase the risks of pathogen and pest spread from stumps to nearby conspecific trees to which they are connected with root grafts (LevYadun 2011).

We studied stump sprouting in a forest managed for timber in Suriname where the trait is undesired but little studied. Our main objective was to determine the likelihood of sprouting for canopy tree species, in relation to stump diameter and height, bark thickness and canopy openness. The presence of stumps that resulted from an experimental silvicultural treatment designed to liberate future crop trees of commercial species from competition from nearby neighbours allowed us to study a wider range of stem diameters than created by selective logging alone. We also inspected the area for sprouted stumps from the previous round of logging some 25 years prior to our study.

\section{MATERIALS AND METHODS}

\section{Study site}

Characteristics of stump sprouts were measured in mesophytic tropical rainforest (Lindeman \& Moolenaar 1959) in the N.V. Takt Timber Concession in the Mapane region of Suriname $\left(5^{\circ} 11^{\prime} \mathrm{N}, 54^{\circ} 50^{\prime} \mathrm{W}\right)$. The well-drained red Ferrasol (Oxisol) in the area is nutrient poor. The mean annual temperature is $27^{\circ} \mathrm{C}$ and the area receives $1700-2500 \mathrm{~mm}$ of precipitation annually but often suffers water deficits during the August-March dry season. The general area was selectively logged about 25 years prior to our study, but no information was available about the species harvested and logging intensity. The 35-ha study area on which we focused was selectively logged and silviculturally treated 13-18 months prior to our measurements. Treatment involved felling of trees overtopping designated future crop trees (i.e. liberation thinning).

\section{Field data collection and data analysis}

To locate stumps of harvested trees and those of trees felled as part of the liberation treatment, we used harvest plan stem maps and traversed the area thoroughly. When we encountered a stump, we determined whether or not it supported live or dead sprouts, identified it to species, and measured its diameter, height (on the uphill side), and bark thickness at $50 \mathrm{~cm}$ above the ground. We also classified the heartwood of each stump as either sound or rotten, and with or without termites. To characterise the stump environment, we estimated percent canopy openness with a canopy densiometer (Lemmon 1956), measured slopes $5 \mathrm{~m}$ above and below each stump with a clinometer, and assigned a topographic position (i.e. ridge top, slope or valley bottom) to each stump encountered. We also searched for sprouted stumps from the trees felled about 25 years prior to our study. All analyses were performed using $\mathrm{R}$ software version 3.6.1 (R Core Team 2019) with significance set at $\alpha<0.05$.

\section{RESULTS}

Of the 120 stumps of 33 species encountered, 57 sprouted; the sprouts were dead on seven of the 
sprouted stumps (Figure 1). Among the species with the most abundant stumps, sprouting was common in Dicorynia guianensis (18 of 23; after first mention, species are referred to by their generic names; see Appendix for the complete list of species and the raw data) and Eperua falcata (5 of 10). In contrast, sprouting was rare in Qualea rosea (6 of 40). The proportions of sprouted stumps differed between the three common species $\left(\chi^{2}=24.9, \mathrm{p}<0.005\right)$. After sprouting, all sprouts died on one Dicorynia stump and four Qualea stumps. In Tetragastris, 2 of 5 stumps sprouted and in Pseudopiptadenia and Goupia, 3 of 5 stumps sprouted. In the remaining 23 species represented by only 1 stump, 12 sprouted of which 2 died and 11 did not sprout.

Considering all the stumps we surveyed, those that sprouted were smaller in diameter (mean \pm 1 standard deviation; $\overline{\mathrm{x}}=54.4 \pm 2.68 \mathrm{~cm}, \mathrm{n}=57$ ) than stumps that did not sprout $(\overline{\mathrm{x}}=63.2 \pm 2.39 \mathrm{~cm}$, $\mathrm{n}=63, \mathrm{t}=2.45, \mathrm{p}<0.02$; Figure 2 ). This communitylevel pattern was not maintained for the species with more than nine stumps (Dicorynia, Eperua and Qualea).

At the community level (i.e. with all stumps considered of all species) there was no difference in stump height for sprouted stumps $(\overline{\mathrm{x}}=98.1 \pm$ $3.93 \mathrm{~cm}, \mathrm{n}=57)$ and stumps that did not sprout $(\overline{\mathrm{x}}=93.5 \pm 2.98 \mathrm{~cm}, \mathrm{t}=0.95, \mathrm{p}=0.34, \mathrm{n}=63$; Figure $3)$. In contrast, in one of the species represented by more than nine stumps (Qualea), sprouted stumps $(\overline{\mathrm{x}}=115.1 \pm 9.49 \mathrm{~cm}, \mathrm{n}=10)$ were taller than non-sprouted stumps $(\overline{\mathrm{x}}=95.6 \pm 4.05 \mathrm{~cm}, \mathrm{n}$ $=30, \mathrm{t}=2.20, \mathrm{p}=0.03) ;$ Dicorynia showed a similar tendency while Eperua did not.

In regards to bark thickness, when we considered all trees of all species (Figure 4), the bark on stumps that did not sprout $(\overline{\mathrm{x}}=11.1 \pm$

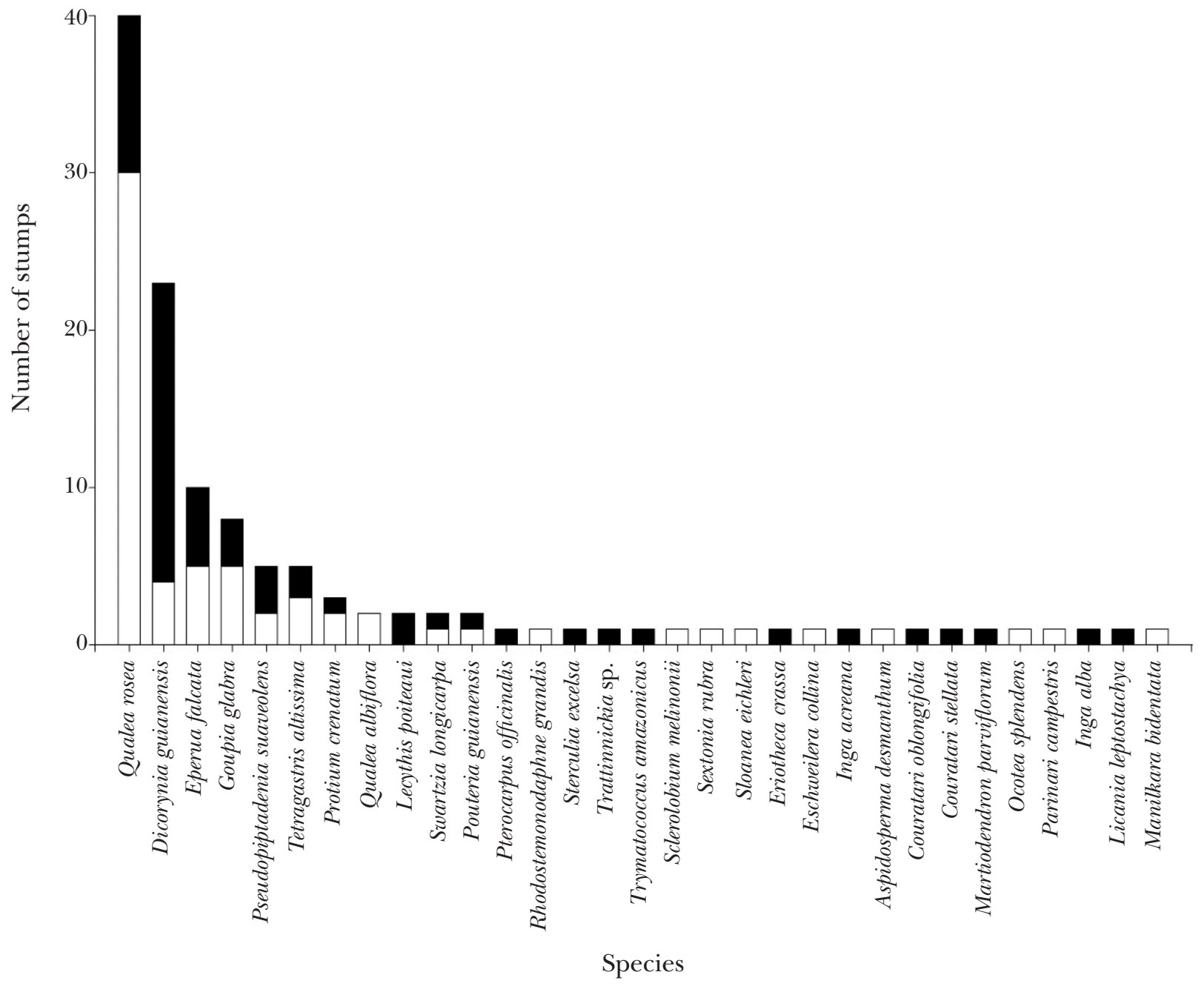

Figure 1 The number of sprouted (black bars) and non-sprouted (white bars) stumps of 33 species of canopy trees cut 13-18 months prior to this survey 

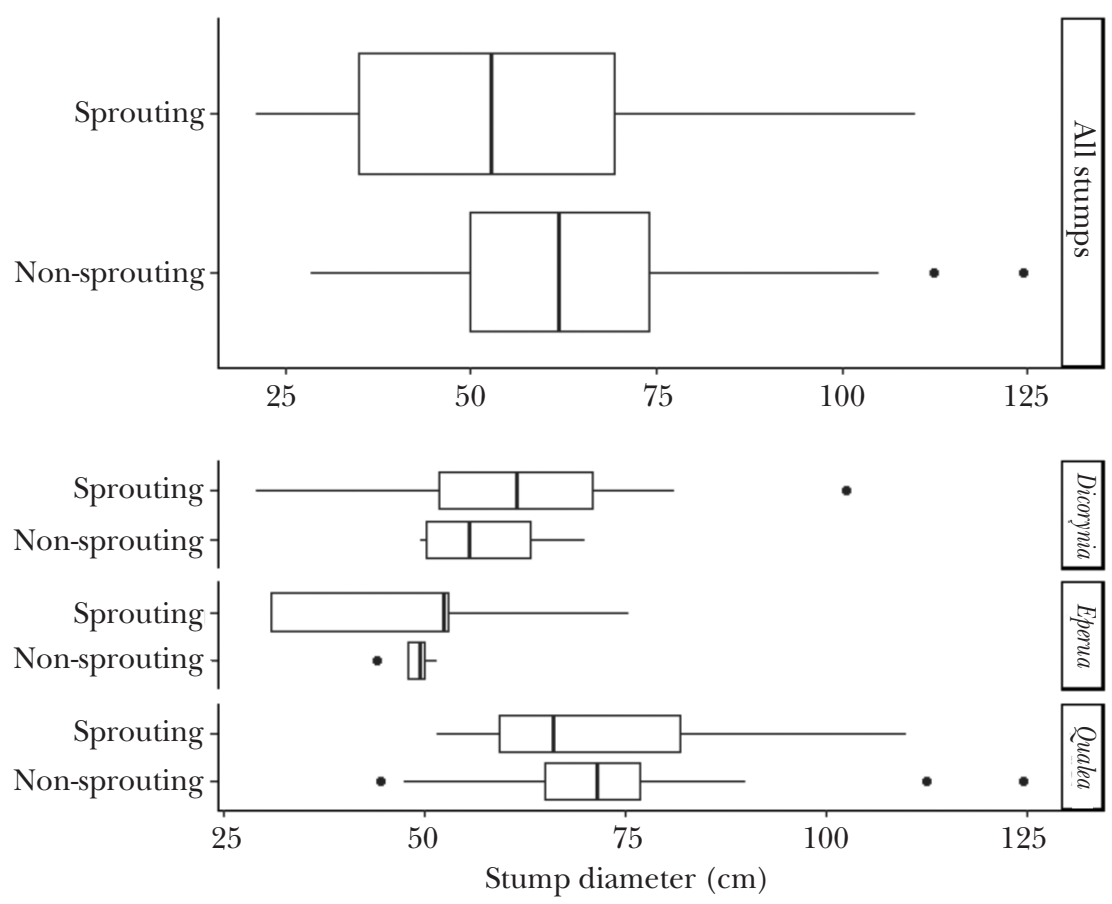

Figure 2 Diameters of sprouted and not-sprouted stumps of all 33 species and the three species with more than nine stumps
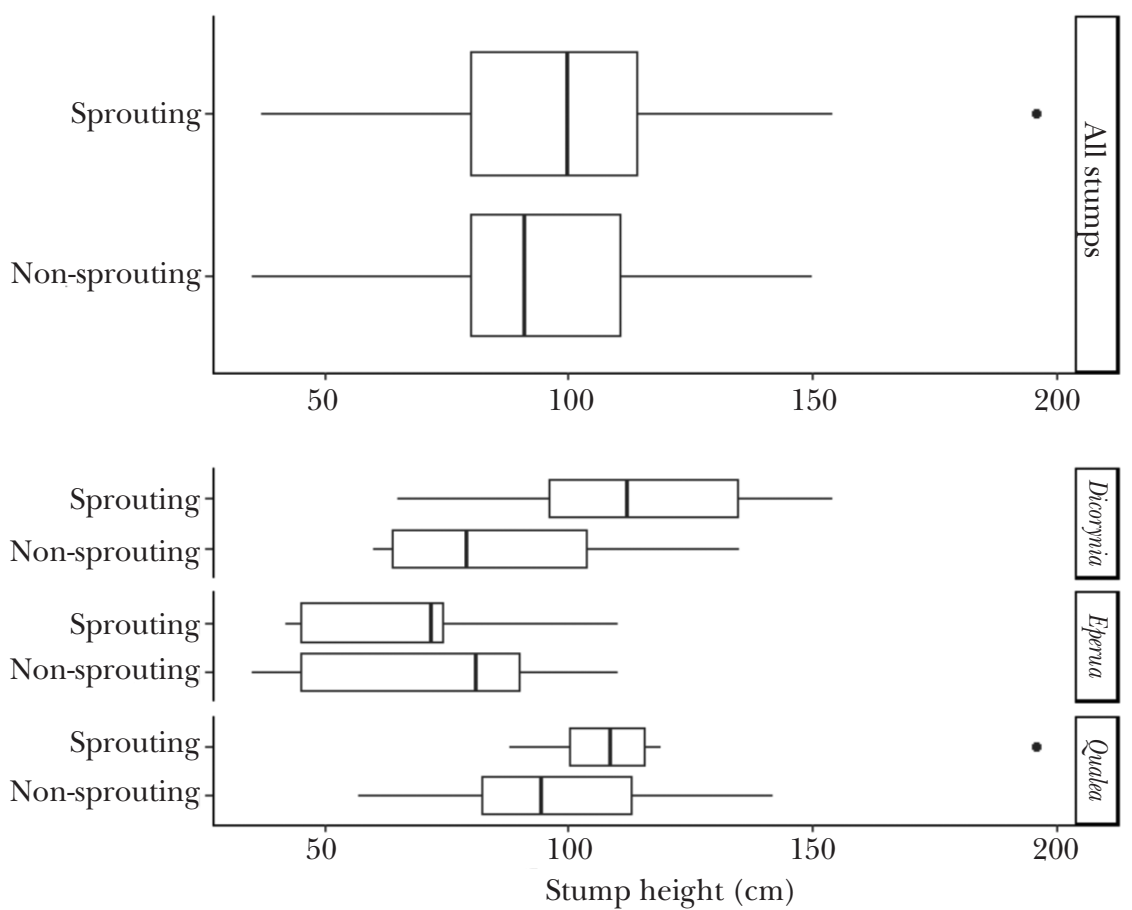

Figure 3 Heights of sprouted and non-sprouted stumps of all 33 species and the three species with more than nine stumps

$17.54 \mathrm{~mm}, \mathrm{n}=63$ ) was thicker than on stumps that did sprout $(\overline{\mathrm{x}}=8.7 \pm 15.05 \mathrm{~mm}, \mathrm{n}=57, \mathrm{t}=3.03$, $\mathrm{p}<0.01)$. In contrast, comparisons of sprouted and non-sprouted stumps of the species with sample sizes of more than nine stumps showed no differences in bark thickness.
Among the environmental variables potentially associated with stump sprouting (topography, soil drainage, soil type, and canopy openness), only canopy openness showed any trend, but none of the differences were significant (Figure 5). 

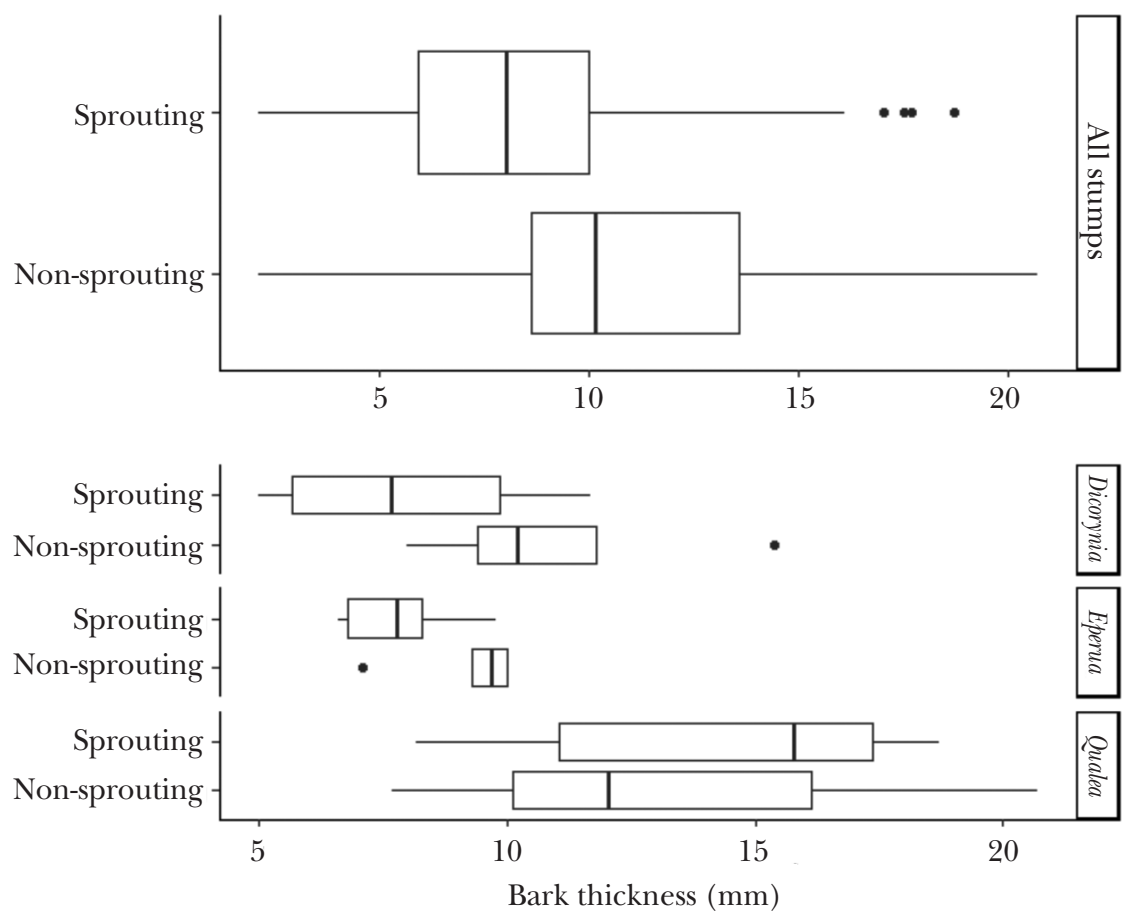

Figure 4 Bark thickness of sprouted and non-sprouted stumps of all 33 species and the three species with more than nine stumps
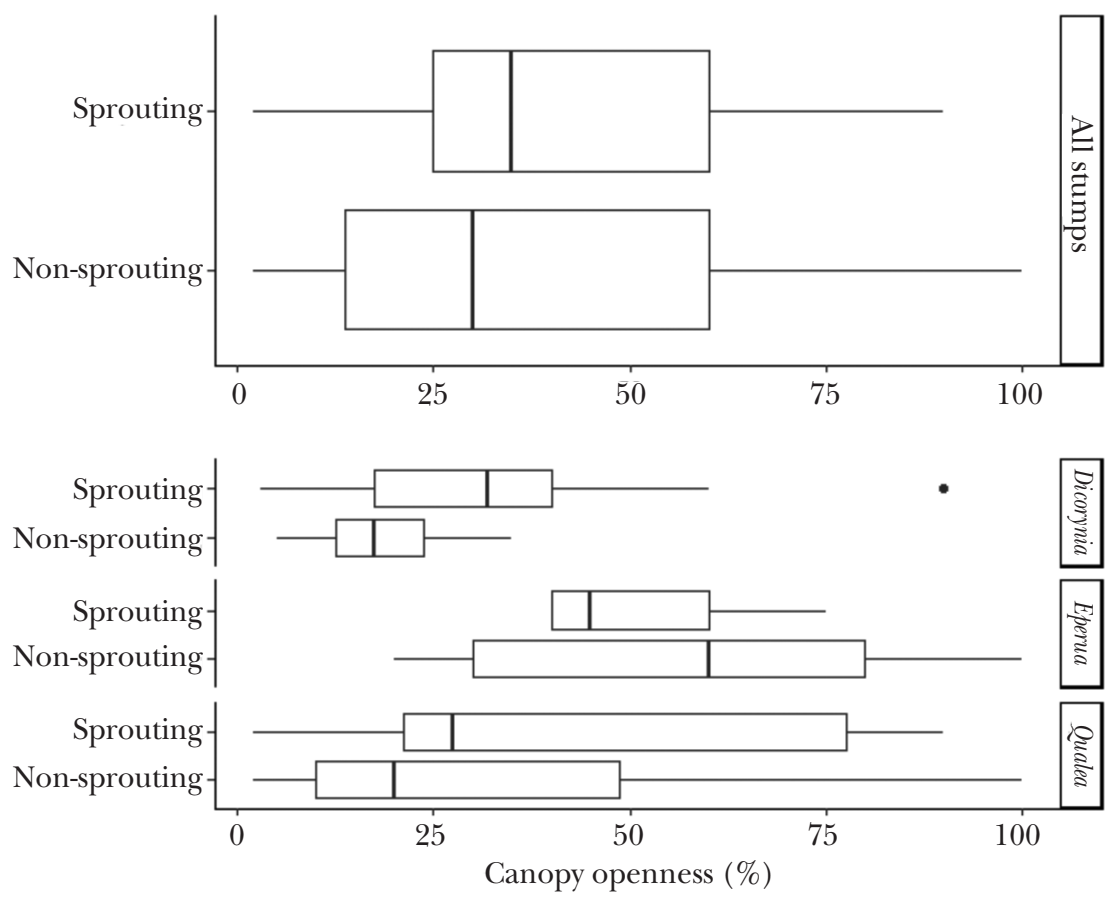

Figure 5 Canopy openness (\%) over sprouted and non-sprouted stumps of all 33 species and the three species with more than nine stumps

\section{DISCUSSION}

In the selectively logged and silviculturally treated lowland tropical forest we studied in Suriname, slightly less than half of the stumps supported live sprouts 13-18 months after felling. This relatively low proportion perhaps reflected the large sizes of the stumps we surveyed, which averaged $>50 \mathrm{~cm}$ in diameter with none less than $25 \mathrm{~cm}$. Numerous other studies reported that sprouting decreases with stump diameter (Lust \& Mohammady 1973). We observed a weak but 
significant trend in our forest, but those other studies focused on much smaller trees. We expected but did not find that the likelihood of sprouting increased with stump height but, as with diameter, the range of stump heights in our study was small (Figure 3). As expected, at least at the community level, the likelihood of sprouting decreased with bark thickness. In contrast, within the three well-sampled species, sprouting did not vary with bark thickness perhaps because many sprouts on one of them (E. falcata) emerged from the exposed vascular cambium on the cut surface of the stump and thus avoided the need to penetrate the bark (Ramdial et al. 2020). Also contrary to multiple reports in the literature (Lust \& Mohammady 1973, Pelc et al. 2011), we observed no relationship between canopy opening and whether or not stumps sprouted. We note that the range of canopy openness above the stumps we studied was small and most received substantial light. This observation was to be expected given that the stumps were created by the felling of canopy trees, which would assure at least some light reaching down to the stumps. Perhaps the effect of light intensity on stump sprouting was only evident among stumps in deeper shade than observed in our study.

We searched for but did not find the large, multiple-stemmed trees that might indicate stump sprouting after the previous round of selective logging, some 25 years prior to our study. Although all the sprouts were dead on only 7 of the 57 sprouted stumps in our study (of 120), the absence of older stump sprouts suggested that many more will soon die. In contrast, in nearby Guyana, Rijks et al. (1998) reported that 20 years after logging, $55 \%$ of the Chlorocardium rodiei (greenheart) stumps still supported live sprouts of up to $8.1 \mathrm{~cm}$ diameter at breast height. That finding notwithstanding, given their vulnerability to diseases that enter through the stump and their inherent biomechanical instability, stump sprouts rarely grow into large trees with sound boles. Nevertheless, even if sprouts are relatively short-lived, they use resources that might otherwise be available to small trees with better prospects for longevity and good form. For this reason, we recommend that, at least for silvicultural treatments that involve liberation of future crop trees from competition from neighbours, instead of felling the competitors, they be poison-girdled. This treatment eliminates resprouting and reduces the stand damage done when the competitor finally falls.

\section{ACKNOWLEDGEMENTS}

This study was funded by REDD+ Suriname. Working conditions in the Mapane Camp were improved substantially by the food prepared by Tilborg Marciano. Transportation and field assistance were provided by our bus driver, Austin Jurgen. Finally, stump identification was only possible due to the contributions of two very experienced forest workers, Hubert $\mathrm{J}$ and Anielkoemar S.

\section{REFERENGES}

Bellingham P \& Sparrow A. 2000. Resprouting as a life history strategy in woody plant communities. Oikos 89: 409-416. https://doi.org/10.1034/j.16000706.2000.890224.x

BYEr M \& WEAVER P. 1977. Early succession in elfin woodland in Luquillo Mountains of Puerto Rico. Biotropica 9: 35-47.

Clark D \& Clark D. 1991. The impact of physical damage on canopy tree regeneration in tropical rainforest. Journal of Ecology 79: 447-457.

Clarke PJ, Lawes MJ, Midgley JJ et al. 2013. Resprouting as a key functional trait: how buds, protection and resources drive persistence after fire. New Phytolologist 197: 19-35. https://doi.org/10.1111/nph.12001

Coomes DA \& GRuBB PJ. 2000. Impacts of root competition on forests and woodlands: a theoretical framework and review of experiments. Ecological Monographs 70: 171-207. https://doi.org/10.1890/00129615(2000)070[0171:IORCIF]2.0.CO;2

De Rouw A. 1993. Regeneration by sprouting in slash and burn rice cultivation, Tai rain forest, Cote d'Ivoire. Journal of Tropical Ecology 9: 387-408.

Del Tredici P. 2001. Sprouting in temperate trees: a morphological and ecological review. Botanical Review 67: 121-140. https://doi.org/10.1007/BF02858075

Evans J. 1992. Coppice forestry-an overview. Pp 18-27 in Buckley GP (ed) Ecology and Management of Coppice Woodlands. Chapman \& Hall, London.

Everham E \& BrokaW N. 1996. Forest damage and recovery from catastrophic wind. Botanical Review 62: 113-185.

EWEL J. 1977. Differences between wet and dry successional tropical ecosystems. Geo-Eco-Trop 1: 103-117.

Fuashi NA, Ayamba AJ \& Orock AE. 2020. The role of logged timber stump sprouting in natural forest regeneration in the Akak forest area of Cameroon. Journal of Ecology and the Natural Environment 12: 9-21. https://doi.org/10.5897/JENE2019.0781

ICkes K, Dewalt S \& Thomas S. 2003. Resprouting of woody saplings following stem snap by wild pigs in a Malaysian rainforest. Journal of Ecology 91: 222-233. https://doi.org/10.1046/j.1365-2745.2003.00767.x

Keim RF, Chambers JL, Hughes MS et al. 2006 Long-term success of stump sprouts in high-graded baldcypresswater tupelo swamps in the Mississippi delta. Forest Ecology and Management 234: 24-33. doi:10.1016/j. foreco.2006.06.015 
Lemmon PE. 1956. A spherical densiometer for estimating forest overstory density. Forest Science 2: 314-320.

LEV-YADUN S. 2011. Why should trees have natural root grafts? Tree Physiology 31: 575-578. https:/ / doi.org/10.1093/ treephys/tpr061

Lindeman JC \& MoolenaAr SP. 1959. Preliminary survey of the vegetation type of the northern Suriname. The Vegetation of Suriname 1: 1-45.

Lust N \& Mohammady M. 1973. Regeneration of coppice. Sylva Gandavensis 39: 1-29

Mwavu EN \& Witkowski ETF. 2008. Sprouting of woody species following cutting and tree-fall in a lowland semi-deciduous tropical rainforest, north-western Uganda. Forest Ecology and Management 225: 982-992. https://doi.org/10.1016/j.foreco.2007.10.018

Paciorek C, Condit R, Hubbell S \& Foster R. 2000. The demographics of resprouting in tree and shrub species of a moist tropical forest. Journal of Ecology 88: 765-777. https://doi.org/10.1046/j.13652745.2000.00494.x

Pelc BD, Montgomery RA \& Reich PB. 2011. Frequency and timing of stem removal influence Corylus americana resprout vigor in oak savanna. Forest Ecology and Management 261: 136-142. https://doi. org/10.1016/j.foreco.2010.09.043

Peltier R, Dubiez E, Diowo S et Al. 2014 Assisted natural regeneration in slash-and-burn agriculture: results in the Democratic Republic of the Congo. Bois et Forêts des Tropiques 321: 67-79. https:// doi.org/10.19182/ bft2014.321.a31220

Putz FE \& BrokaW N. 1989. Sprouting of broken trees on Barro Colorado Island, Panama. Journal of Ecology 70: 508-512.

Putz FE \& Canham CD. 1992. Mechanisms of arrested succession in shrublands: root and shoot competition between shrubs and tree seedlings. Forest Ecology and Management 49:267-275.

Rackнам O. 1980. Ancient Woodlands: Its History, Vegetation and Uses in England. Edward Arnold, London.

Ramdial D, Sewdien A, Rasdan J et al. 2020. Stump sprout characteristics of three commercial tree species in Suriname. Forests 11: 1130. https://doi.org/10.3390/ f11111130

Rijks MH, Malta E-J \& Zagt RJ. 1998. Regeneration through sprout formation in Chlorocardium rodiei (Lauraceae) in Guyana. Journal of Tropical Ecology 14: 463-475. https://doi.org/10.1017/S0266467498000340

STOcker G. 1981. Regeneration of a North Queensland rainforest following felling and burning. Biotropica 13: 86-92.

Uhl C, Clark K, Clark H \& Murphy P. 1981. Early plant succession after cutting and burning in the Upper Rio Negro Region of the Amazon Basin. Journal of Ecology 69: 631-649. 
Appendix Stumps of 120 trees of 33 species surveyed for sprouts in a 35-ha block of selectively logged and silviculturally treated forest in Suriname

\begin{tabular}{|c|c|c|c|}
\hline Scientific name & Sprouting & Non-Sprouting & Total \\
\hline Aspidosperma desmanthium & & 1 & 1 \\
\hline Couratari oblongifolia & 1 & & 1 \\
\hline Couratari stellata & 1 & & 1 \\
\hline Dicorynia guianensis & 19 & 4 & 23 \\
\hline Eperua falcata & 5 & 5 & 10 \\
\hline Eriotheca crassa & 1 & & 1 \\
\hline Eschweilera collina & & 1 & 1 \\
\hline Goupia glabra & 3 & 5 & 8 \\
\hline Inga acreana & 1 & & 1 \\
\hline Inga alba & 1 & & 1 \\
\hline Lecythis poiteaui & 2 & & 2 \\
\hline Licania leptostachya & 1 & & 1 \\
\hline Manilkara bidentata & & 1 & 1 \\
\hline Martiodendron parviflorum & 1 & & 1 \\
\hline Ocotea splendens & & 1 & 1 \\
\hline Parinari campestris & & 1 & 1 \\
\hline Pouteria guianensis & & 1 & 1 \\
\hline Protium crenatum & 1 & 1 & 2 \\
\hline Pseudopiptadenia suaveolens & 3 & 2 & 5 \\
\hline Pterocarpus officinalis & 1 & & 1 \\
\hline Qualea albiflora & & 2 & 2 \\
\hline Qualea rosea & 10 & 30 & 40 \\
\hline Rhodostemonodaphne grandis & & 1 & 1 \\
\hline Sclerolobium melinonii & & 1 & 1 \\
\hline Sextonia rubra & & 1 & 1 \\
\hline Sloanea eichleri & & 1 & 1 \\
\hline Sterculia excelsa & 1 & & 1 \\
\hline Swartzia longicarpa & 1 & 1 & 2 \\
\hline Tetragastris altissima & 2 & 3 & 5 \\
\hline Trattinnickia sp. & 1 & & 1 \\
\hline Trymatococcus amazonicus & 1 & & 1 \\
\hline Grand total & 57 & 63 & 120 \\
\hline
\end{tabular}

